\title{
DESIGNING AN INTERNATIONAL BACHELOR DEGREE SYLLABUS - CORPORATE SOCIAL RESPONSIBILITY IN INDUSTRY 4.0
}

\author{
Andrey Zahariev ${ }^{1 *}$, Angel Angelov ${ }^{2}$, Petko Angelov ${ }^{3}$, Margarita Mihaylova ${ }^{4}$, Slaveyko \\ Slavov ${ }^{5}$ and Stanislav Mladenov \\ ${ }^{1}$ Prof. Dr., D. A. Tsenov Academy of Economics, Svishtov, Bulgaria, \\ andrey.zahariev.1971@gmail.com \\ ${ }^{2}$ Assoc. Prof. Dr., D. A. Tsenov Academy of Economics, Svishtov, Bulgaria, a.angelov@uni- \\ svishtov.bg \\ ${ }^{3}$ Head Assist. Prof. Dr., D. A. Tsenov Academy of Economics, Svishtov, Bulgaria, p.angelov@uni- \\ svishtov.bg \\ ${ }^{4}$ Sen. Lecturer, Dr., D. A. Tsenov Academy of Economics, Svishtov, Bulgaria, m.mihaylova@uni- \\ svishtov.bg \\ ${ }^{5}$ Researcher, National Federation of Employers of Disabled People, Sofia, Bulgaria, \\ slaveykoslavkov@gmail.com \\ ${ }^{6}$ PhD Student, D. A. Tsenov Academy of Economics, Svishtov, Bulgaria, D010221235@uni- \\ svishtov.bg \\ ${ }^{*}$ Corresponding author
}

\begin{abstract}
The project "Adaptation of strategies for corporate social responsibility to address the implications of the Industry 4.0" is currently in the second year of its implementation. It is executed within the ERASMUS+ Program, key activity "Strategic Partnerships in Higher Education" and is coordinated by a team of the "D. A. Tsenov" Academy of Economics (Svishtov, Bulgaria) in partnership with the National Federation of Employers of Disabled People (Sofia, Bulgaria), the Accreditation Council for Entrepreneurial and Engaged Universities (Münster, Germany), the Catholic University of Murcia (Murcia, Spain) and the University of Nis (Nis, Serbia). The project is focused on current challenges of corporate social responsibility as an expression of the impact of organizational activities on society and the environment. Currently, corporate social responsibility is an extremely important factor influencing the development of companies, the formation of their profits and maintaining the image of product brands. Along with their main activity, socially responsible enterprises also perform activities of social significance, such as offering donations, supporting charitable actions, social events, etc. Such companies also award grants and scholarships, provide support to disasteraffected areas and support other aid causes. As an ex post result from the project http://csr-project.eu/ the partners have developed a curricula for a bachelor degree subject entitled "Corporate social responsibility in Industry 4.0" for students in the field of economics, administration and management". As an in medias result the academic lecturers and researchers are on the final stage of writing the content of the academic textbook containing 8 chapters grouped in two parts - theoretical and empirical. The first theoretical part "Theoretical developments of CSR in Industry 4.0" includes the following four chapters: 1) Evolution of corporate social responsibility; 2) Financial and managerial dimensions of CSR; 3) Emerging social challenges with Industry $4.0 ; 4)$ Strategic approach to corporate social responsibility. The second part entitled "Case studies of CSR in Industry 4.0" includes other four chapters: 5) National evidences for implementation of the concept of
\end{abstract}


CSR; 6) CSR and Industry 4.0 - evidences from Spain; 7) CSR and Industry 4.0 - evidences from Germany; 8) CSR and Industry 4.0 - evidences from Bulgaria. As a main conclusion from the paper, we argue that the project "Adaptation of strategies for corporate social responsibility to address the implications of the Industry 4.0" with reference number: 2020-1-BG01-KA203-079025 is an excellent opportunity to create added value through international partnership under the Erasmus + program. The achievements as of the last month of the second stage of the project implementation give grounds to expect its successful completion and achievement of all set goals and objectives. Besides the initial project topic, the Covid-19 environment has opened before all main economic agents - the companies, the households and the government $-\mathrm{a}$ new opportunity to prove the concept of CSR is a vital and important attitude to be more health protecting and ecologically responsible.

Keywords: CSR in Industry 4.0, Erasmus+, Curricula, Syllabus

\section{INTRODUCTION}

The new realities of the Fourth Industrial Revolution have been unfolding much more rapidly and exponentially compared to the changes in the previous industrial revolutions. This sets new social expectations for socially responsible behaviour of business entities. The implications of Industry 4.0, such as changing the employment profile, replacing the workforce with robots, the emergence of new occupations and new skills demanded by the labour market, remote work and reduction in working hours, will impact significantly corporate social responsibility in terms of generating social results and improving productivity. In view of the above, the project focuses on the training of future managers and economists to acquire knowledge and skills important for maintaining the social goals of business in a new environment and new challenges. The new technologies, which are at the heart of the Fourth Industrial Revolution, bring unseen challenges to society, business and people's daily lives. These challenges require different approaches to address them, which have not been known and implemented so far. The viable solutions cannot be found solely through government mechanisms for managing, stimulating and developing the economy: business must also be actively involved in change management. Therefore Industry 4.0 is in the mainstream of the scientific discussion as a new environment of doing business based on the responsibilities to the society welfare. Even more, the idea of the "Green Pact" and the plans of reduction of global warming must be accepted as a form of planetary social responsibility. That is why at the beginning of the third decade of the 21 st century we are talking about a direct link between the concept of corporate social responsibility and the technological environment and driving forces of Industry 4.0. This is set as a problem area for research in this report. It pursues the main justification and the first phases of the practical implementation of the project "Adaptation of strategies for corporate social responsibility to address the implications of the Industry 4.0" with reference number: 2020-1-BG01-KA203-079025, which involves four European countries and five partner institutions.

\section{PROJECT PHILOSOPHY AND RESEARCH METHOD}

\subsection{The project Consortium and First Steps}

The history of the project is based on partner meetings and agreements as it follows:

- The main goal of the project is to develop a training course for higher education students in economics on the consequences of Industry 4.0 and the emerging challenges in the overall performance of enterprises and the social impact of business activities.

- The study material is focused on applying interdisciplinary links, further developing the understanding of the constituent elements of Industry 4.0 and filling existing gaps in preparing students for the main areas of benefits from Industry 4.0.

The project consortium includes "D. A. Tsenov" Academy of Economics (Svishtov, Bulgaria) as a project coordinator in partnership with the National Federation of Employers of Disabled People (Sofia, Bulgaria), the Accreditation Council for Entrepreneurial and Engaged Universities (Münster, Germany), the Catholic University of Murcia (Murcia, Spain) and the University of Nis (Nis, Serbia).

The project has the following specific objectives:

- To identify gaps in existing programs regarding corporate social responsibility in the era of Industry 4.0. 
- To select teaching materials, pedagogical approaches and aids;

- To develop a training course and a teacher's manual;

- To prepare a set to support teaching and learning.

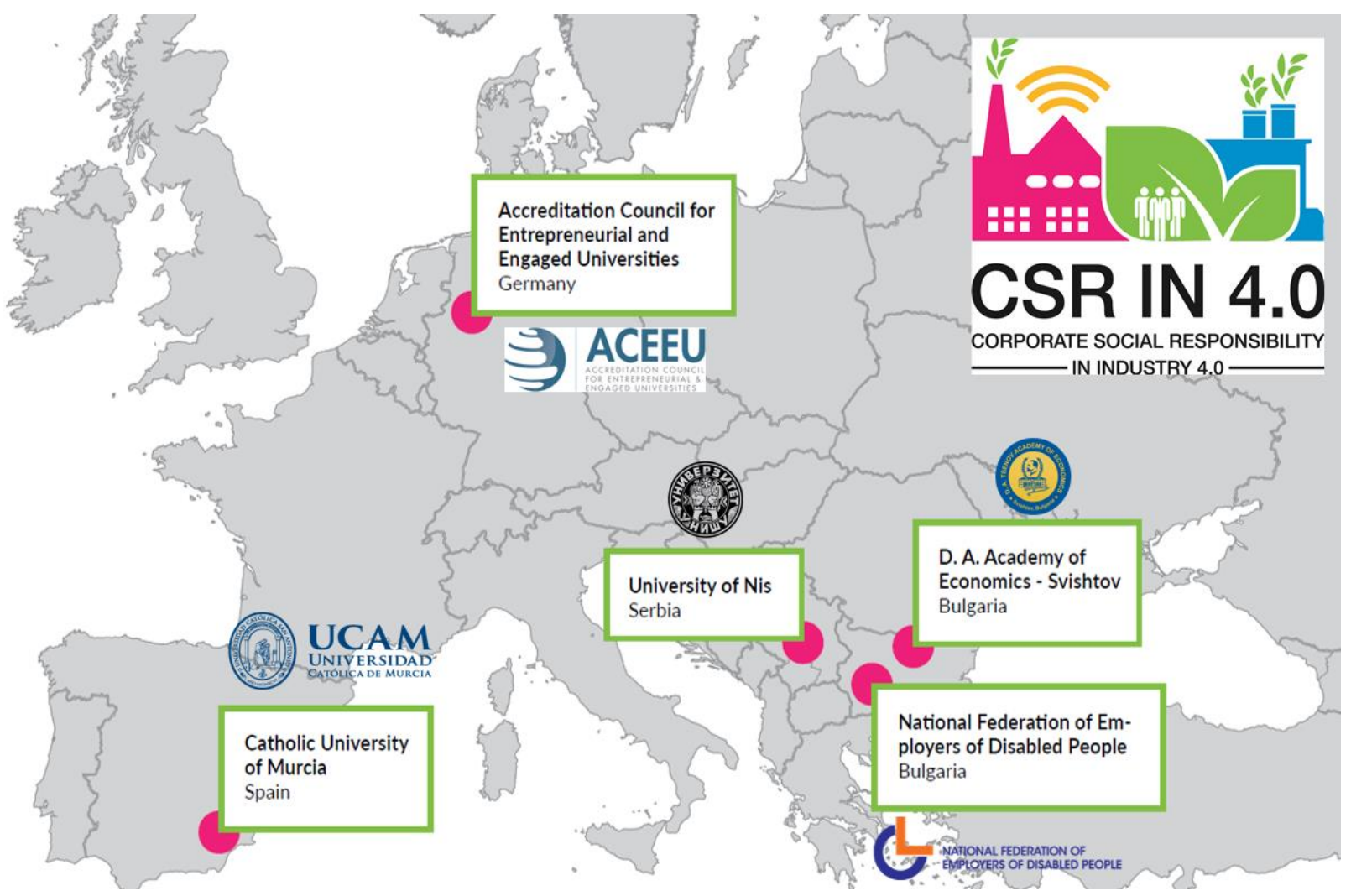

Fig. 1. Project consortium and project logo

The project is intended for the following target groups:

- Higher education students in economics, administration and management;

- Academic staff in higher education institutions working on the topic of Industry 4.0 and its social dimensions;

- Business practitioners;

- Experts in corporate governance, corporate responsibility and economic development.

The project purpose is to achieve the following results: outlining areas of complementarity with the topic of corporate social responsibility in the context of Industry 4.0 in specific subjects taught according to existing curricula; providing for country-specific information on the extent, level of coverage and implementation of the EU approach to corporate social responsibility on the changing economic environment due to Industry 4.0 in the field of student knowledge development; identifying shortfalls in current business and management programmes at universities regarding the challenges to corporate social responsibility; expanding the base for understanding and coping with the reality of the trends in internationalization, globalization and digitalization in the national and world economy; stimulating the entry of the academic staff and students into contacts with various business entities; providing for support by specialists in corporate social responsibility to strengthen the prospects for setting social goals for businesses and transfer these ideas to graduates; increasing the attractiveness of dealing with the social economy and social entrepreneurship in parallel to achieving the main business goals; providing for a practical support tool for university professors working on corporate economics to improve their understanding of the need to introduce emerging aspects of corporate social responsibility and further develop students' knowledge in order to prepare them for the complexity of the globalizing economy; encouraging the exchange of views on obstacles to the further integration of the topic of corporate social responsibility in the context of Industry 4.0 and on the improvement of training 
programs; developing a multilingual online platform for the exchange of knowledge, advice and feedback; expanding learners' understanding and skills in areas such as digitalisation, successful employment, active citizenship, social inclusion, equal opportunities and personal change management.

The overall implementation of the project is designed in the following three main phases:

- Phase 1. Competence framework and curriculum (IO1);

- Phase 2. Training course on the impact of Industry 4.0 on CSR (IO2);

- Phase 3. Lecturer's manual with support set (IO3).

Each of these phases comprises a package of activities for the development of methodological material or training content related to its name.

\subsection{Implementation of the First Phase of the Project - Syllabus Concept}

The implementation of the first phase of the competence framework ended with the execution of the following activities: - Review of the available methodology; - Question sets preparation (3 packages); Survey among lecturers; - Survey among students; - Survey among business experts; - Data analysis; Development of the competences framework; - Development of the curriculum; - Adaptation of the national versions of the partner organizations; - Consultation and collecting feedback.

During the implementation of the actual activities for the preparation of educational content, the project team also executed activities for management and for ensuring awareness and publicity of the results and the funding received from the EC. For example, online and face-to-face partnership meetings were organized (one each in Nis and Munster, with forthcoming meetings in Murcia and Sofia), meetings to introduce and promote the project (over 15 meetings with local representatives and 4 in international format) and contacts with a number of large companies (over 20). The project has its own website (https://csr-project.eu) and a Facebook page (https://www.facebook.com/CSRin4.0).

The CSR in Industry 4.0 curricula is divided in two major parts: theoretical and case-study oriented.

\section{Part one. Theoretical developments of CSR in Industry 4.0}

Topic 1. Evolution of corporate social responsibility (CSR) [Research unit and authors from University of Nish, Serbia]

\subsection{The nature of corporate social responsibility}

1.2. Determining the elements of corporate social responsibility

1.3. The concept of corporate social responsibility adopted by the European Union

1.3.1. Internal dimension of corporate social responsibility

1.3.2. External dimension of corporate social responsibility (Zahariev, et al., 2020a)

1.4. Ethics and socially responsible behaviour of the company towards stakeholders

1.4.1. Ethical and responsible behaviour of the company towards employees

1.4.2. Measures of socially responsible behaviour towards employees

1.4.3. Ethical and responsible behaviour of companies towards consumers

1.4.4. Socially responsible behaviour of the company towards the social community

1.4.5. Ethical and socially responsible behaviour of companies towards suppliers

1.4.6. Non-ethical practices of the company towards the social community

Chapter 2. Financial and managerial dimensions of CSR [Research unit and authors from D. A. Tsenov Academy of Economics, Svishtov, Bulgaria]

2.1. The CSR model for human capital investments (Zahariev, Mihaylova, Monev, \& Dikov, 2021b)

2.2. The accounting issue for funding CSR initiatives

2.3. Budgeting framework for CSR implementation cost (Zahariev A. , et al., 2020c)

2.4. Marketing approach for involvement of corporate financing and social initiatives support. 
2.4.1. Management framework for promoting corporate causes

2.4.2. CSR and cause-related marketing

2.4.3. Dimensions of socially responsible measures of the company - volunteering for the community, philanthropy, accepting social goals

2.4.4. Corporate social marketing - brand, trade name and label

2.5. Standards for CSR

2.5.1. Measurement and proofing of CSR

2.5.2. International standards for CSR

2.5.3. CSR standards in HR management

2.5.4. Quality standards for CSR

2.5.5. Ecological standards for CSR

2.5.6. CSR standards for safety and health workplace conditions

Chapter 3. Emerging social challenges with Industry 4.0 [Research unit and authors from D. A. Tsenov Academy of Economics, Svishtov, Bulgaria and National Federation of Employers of Disabled People, Sofia, Bulgaria]

3.1 Vulnerability of systems (Sabitova, Shavaleyeva, Lizunova, Khairullova, \& Zahariev, 2020b)

3.2. European fiscal harmonization and taxation treatment of CSR initiatives. Shadow economy and tax evasion. (Belev, Schneider, Djankov, Zahariev, \& others, 2003)

3.3. Profound changes in education and generation $Z$ challenges.

3.4. CSR in Industry 4.0 project management - step-by-step approach.

3.5. CSR and Covid-19 pandemic. (Adamov, Kolev, Vrachovski, Zahariev, \& Marcheva, 2010)

Chapter 4. Strategic approach to corporate social responsibility [Research unit and authors from University of Nish, Republic of Serbia]

4.1. Advantages of strategic approach to corporate social responsibility

4.2. Formulation of corporate social responsibility strategy

4.2.1. Environmental analysis

4.2.2. Choice of area of company engagement in society

4.2.3. Formulation of vision, social goals and strategic guidelines

4.3. Implementation of corporate social responsibility strategy

4.3.1. Communication of socially responsible initiatives

4.3.2. Monitoring and control of the execution of activities and collection of feedback

4.3.3. Possible errors in the application of CSR activities

4.4. CSR organizational aspects

4.4.1. Actions versus intentions

4.4.2. Corporate commitment

4.4.3. Voluntary versus mandatory

4.4.4. Stakeholder activism

4.5. CSR business aspects (diversity, sustainability, fair trade, wages) (Zahariev A. , 2012)

Part two. Case studies of CSR in Industry $\mathbf{4 . 0}$

Chapter 5. National evidences for implementation of the concept of CSR 
5.1. Development of corporate social responsibility in Bulgaria [Research unit and authors from National Federation of Employers of Disabled People, Sofia, Bulgaria]

5.1.1. Institutional environment

5.1.2. Level of population awareness or importance of corporate social responsibility (Zahariev A. , et al., 2020d)

5.1.3. Socially responsible company practice (Zahariev, Simeonov, \& Zaharieva, 2021c)

5.2. Development of corporate social responsibility in Germany [Research unit and authors from the Accreditation Council for Entrepreneurial and Engaged Universities, Münster, Germany]

5.2.1. Institutional environment

5.2.2. Level of population awareness or importance of corporate social responsibility

5.2.3. Socially responsible company practice

5.3. Development of corporate social responsibility in Spain [Research unit and authors from the Catholic University of Murcia, Spain]

5.3.1. Institutional environment

5.3.2. Level of population awareness or importance of corporate social responsibility

5.3.3. Socially responsible company practice in Spain

5.4. Development of corporate social responsibility in Serbia [Research unit and authors from University of Nish, Serbia]

5.4.1. Institutional environment

5.4.2. Level of population awareness or importance of corporate social responsibility

5.4.3. Socially responsible company practice

Chapter 6. CSR and Industry 4.0 - evidences from Spain [Research unit and authors from the Catholic University of Murcia, Spain]

6.1. Unemployment caused by the new technologies - case study from Spain (Zaharieva \& Sylqa, 2020)

6.1. Social and legal aspects of CSR (outsourcing, corruption, human rights, patents) - case study from Spain

Chapter 7. CSR and Industry 4.0 - evidences from Germany [Research unit and authors from the Accreditation Council for Entrepreneurially Engaged Universities, Münster, Germany]

7.1. Emerging Information technologies coming with the Industry 4.0 (case study from Germany)

7.1.1. CSR and Internet of Things

7.1.2. CSR and Artificial Intelligence

7.1.3. CSR and Cloud Computing (Zahariev, Mihaylova, Monev, \& Dikov, 2021b)

7.1.4. CSR and Big data

7.1.5. CSR and 3D printing

7.1.6. CSR and Blockchain

7.1.7. CSR and Robotics

7.1.8. CSR and Virtual reality and augmented reality

7.2. Emerging manufacturing technologies coming with the Industry 4.0 (case study from Germany):

7.2.1. CSR and Robotics, unmanned systems, autonomous vehicles

7.2.2. CSR and adding manufacturing (Laktionova, Dobrovolskyi, Karpova, \& Zahariev, 2019)

Chapter 8. CSR and Industry 4.0 - evidences from Bulgaria [Research unit and authors from National Federation of Employers of Persons with Disabilities, Sofia, Bulgaria] 
8.1. CSR and social legitimacy (case study from Bulgaria) (Zahariev, Radulova, Aleksandrova, \& Petrova, 2021a)

8.2. CSR and employment of disabled people (case study from Bulgaria) (Zahariev \& Zaharieva, 2003)

\subsection{The second Phase of the Project and Scientific Dissemination}

The second phase in the development of the training course is to be completed in January 2022 and its implementation goes through the following stages: - Designing the sections of the course; - Analysis of educational needs; - Selection of materials for introductory training; - Development of detailed structure of the topics and lessons; - Adaptation of learning excerpts; - Development of educational content on relevant topics; - Adaptation and final edit work. The detailed structure of the chapters of the textbook comprises the following parts: Introduction to the chapter (1/2 - 1 page) including its objectives, description of the knowledge and skills to be achieved and the titles of its main sub-chapters; Content of the main body within approx.. 20 pages for part 1 of the textbook and approx. 10 pages for part 2 and a Final section of each chapter comprising: Recommended additional sources ( 5-10 sources); Keywords (5-10 keywords); Questions for self-evaluation and discussion (5-10 questions) and Summary (1/2 - 1 page).

As a scientific dissemination and with regard to the relationship of CSR and the global COVID-19 pandemic the following scientific reports were presented in the second half of 2021 as a part of international scientific events in Ukraine, Serbia and Bulgaria:

First. International scientific-practical conference "Transformation of socio-economic systems in the context of the challenges faced by global economic development", Faculty of Economics at Vasyl' Stus Donetsk National University, 7-8 October 2021, Vinnytsia with report "Corporate social responsibility under Covid-19 circumstances: Bulgarian business attitude", (Zahariev A. , 2021d);

Second. International Scientific Conference "Emerging trends in global and national economy" organised by the Faculty of Economics, University of Nish, 14 October 2021 with report "Corporate social responsibility in Covid-19 environment: evidence from Serbia and Bulgaria", (Ivanovic-Djukic, Zahariev, \& Lepojevic, 2021e);

Third. International scientific and practical conference "Sustainable development and socioeconomic cohesion in the 21st century: trends and challenges", Svishtov, 8th - 9th November 2021, dedicated to the 85th anniversary since the establishment of $\mathrm{D}$. A. Tsenov Academy of Economics, with report (in Bulgarian language): "Measuring the impact of the Covid-19 pandemic on corporate social responsibility policies in Bulgaria" (Zahariev A. , 2021f).

As a result of the second phase and scientific dissemination of the project result it is proved that the Universities in $21^{\text {st }}$ century are an active engine of acceptance the culture of CSR (Terziev V. , 2019, p. 324) among students with training in favour to the national (Ivanov, 2020b) and global labour markets (Terziev \& Ivanov, 2020a, p. 6), (Terziev, Lyubcheva, \& Mihailova, 2021).

\section{CONCLUSION}

The project "Adaptation of strategies for corporate social responsibility to address the implications of the Industry 4.0" with reference number: 2020-1-BG01-KA203-079025 is an excellent opportunity to create added value through international partnership under the Erasmus + program. The achievements as of the last month of the second stage of the project implementation give grounds to expect its successful completion and achievement of all set goals and objectives. Besides the initial project topic, the Covid-19 environment gives to all main economic agents - the companies, the households and the government - a new opportunity to prove the concept of CSR is a vital and important attitude to be more health protecting and ecologically responsible.

\section{ACKNOWLEDGEMENT}

This research was financially supported by the Academic Foundation "Prof. Dr. Minko Roussenov", Svishtov, Bulgaria (Grant No. 1002201) and the Institute of Scientific Research at D. A. Tsenov Academy of Economics, Svishtov, Bulgaria.

\section{REFERENCE LIST}


Adamov, V., Kolev, K., Vrachovski, D., Zahariev, A., \& Marcheva, A. (2010, January). Human resources of the health system in Republic of Bulgaria. Cahiers de sociologie et de démographie médicales, 1(50), 1-126. Retrieved from www.bit.ly/3njV3lz

Belev, B., Schneider, F., Djankov, S., Zahariev, A., \& others. (2003). The informal economy in the EU accession countries Size, Scope, Trends and Challenges to the Process of EU Enlargement. Sofia: CSD. Retrieved from https://www.researchgate.net/publication/336641198

Ivanov, I. (2020b). The labor market in the conditions of a pandemic crisis in Bulgaria. Society and Health, $1(2), 40-55$.

Ivanovic-Djukic, M., Zahariev, A., \& Lepojevic, V. (2021e). Corporate social responsibility in Covid-19 environment: evidence from Serbia and Bulgaria. Proceedings of the International Scientific Conference: Emerging trends in global and national economy, (pp. 239-250). Faculty of Economics, University of Nish.

Laktionova, O., Dobrovolskyi, O., Karpova, T. S., \& Zahariev, A. (2019). Cost Efficiency of Applying Trade Finance for Agricultural Supply Chains. Management Theory and Studies for Rural Business and Infrastructure Development, 41(1), 62-73. doi:https://doi.org/10.15544/mts.2019.06

Sabitova, N. M., Shavaleyeva, C. M., Lizunova, E. N., Khairullova, A. I., \& Zahariev, A. (2020b). Tax Capacity of the Russian Federation Constituent Entities: Problems of Assessment and Unequal Distribution. In S. L. Gabdrakhmanov N., Regional Economic Developments in Russia (pp. 79-86). Springer. doi: https://doi.org/10.1007/978-3-030-39859-0_7

Terziev, V. (2019). The role of business in society. Proceedings of SOCIOINT 2019, 6th International Conference on Education, Social Sciences and Humanities, 24-26 June 2019 (pp. 324-330). Istanbul, Turkey: International Organization Center of Academic Research.

Terziev, V., \& Ivanov, I. (2020a). The national employment plan in Bulgaria - analysis and opportunities for change. International scientific journal „Internauka», Kiev, Ukraine, 15(95), 6-13.

Terziev, V., Lyubcheva, M., \& Mihailova, K. (2021). The necessity of changes in the higher education in Bulgaria. Abstracts \& Proceedings of INTCESS 2021- 8th International Conference on Education and Education of Social Sciences, 18-19 January, 2021 (pp. 646-657). ISBN: 978-605-06286-1-6: DOI: https://doi.org/10.51508/intcess.202104.

Zahariev, A. (2012). Financial Management of Human Resources. V. Tarnovo: ABAGAR. doi:10.13140/RG.2.1.3561.6402

Zahariev, A. (2021d). Corporate social responsibility under Covid-19 circumstancies: Bulgarian business attitude. Economics and Organization of Management, 3(43), 6-13. doi:https://doi.org/10.31558/2307-2318.2021.3.1

Zahariev, A. (2021f). Measuring the impact of the Covid-19 pandemic on corporate social responsibility policies in Bulgaria (in Bulgarian). International scientific and practical conference "Sustainable development and socioeconomic cohesion in the 21st century: trends and challenges", Svishtov, 8th - 9th November 2021, 1, pp. 67-74. Svishtov. Retrieved from https://dlib.unisvishtov.bg/handle/10610/4505

Zahariev, A., \& Zaharieva, G. (2003, September). HR management in Bulgarian firms - empirical evidences. Dialog(3), 5-36. doi:10.2139/ssrn.2977326

Zahariev, A., Mihaylova, M., Monev, V., \& Dikov, V. (2021b). Upgrading competencies of master's degree students through E-learning in business communications in a foreign language. Abstracts \& Proceedings of SOCIOINT 2021 - 8th International Conference on Education and Education of Social Sciences, 14-15 June 2021 (pp. 25-33). Istanbul: OCERINT. doi:https://doi.org/10.46529/socioint.202103

Zahariev, A., Prodanov, S., Radulova, A., Zaharieva, G., Pavlova, M., Angelov, P., . . Marinova, K. (2020c). The Bank Insolvency: from Lehman Brothers to Covid-19 (international remarks and national peculiarities). 58th International Scientific Conference on Economic and Social Development. Budapest.

Zahariev, A., Prodanov, S., Zaharieva, G., Krastev, L., Kostov, D., Pavlov, T., . . Zdravkov, N. (2020d). The Brokerage Insurance Companies under Covid-19 Framework (the Bulgarian experience). 58th 
International Scientific Conference of Economic and Social Development, Budapest 2020, 04-05 September 2020, Economic and Social Developments (Book ot Proceedings) (pp. 369-383). Cakovez, Croatia, 2021: ISSN 1849-7535. doi:https://dx.doi.org/10.2139/ssrn.3688949

Zahariev, A., Radulova, A., Aleksandrova, A., \& Petrova, M. (2021a). Fiscal sustainability and fiscal risk in the EU: forecasts and challenges in terms of COVID-19. Entrepreneurship and Sustainability Issues, 8(3), 618-632. doi:https://doi.org/10.9770/jesi.2021.8.3(39)

Zahariev, A., Simeonov, S., \& Zaharieva, G. (2021c). Management motivation and capital creation through employee stock options - International evidences under covid-19 circumstances. Conference Proceedings/Full Paper of 22nd RSEP International Economics, Finance \& Business Conference Virtual/Online 25-26 August 2021 (pp. 113-120). Istanbul, Turkey: Kadir Has University. Retrieved from www.researchgate.net/publication/354238497

Zahariev, A., Zveryakov, M., Prodanov, S., Zaharieva, G., Angelov, P., Zarkova, S., \& Petrova, M. (2020a). Debt management evaluation through support vector machines: on the example of Italy and Greece. Entrepreneurship and Sustainability Issues, 7(3), 2382-2393. doi:https://doi.org/10.9770/jesi.2020.7.3(61)

Zaharieva, G., \& Sylqa, D. (2020, June 2). Personnel Turnover Management Practices in Bulgaria. Economic Archive, LXXIII(2), pp. 30-42. 